\title{
Access by lesbians, gays, bisexuals and transvestites/transsexuals to the Basic Family Health Units
}

\author{
Acesso de lésbicas, gays, bissexuais e travestis/transexuais às Unidades Básicas de Saúde da \\ Família
}

Geane Silva Oliveira ${ }^{1}$, Jordana de Almeida Nogueira ${ }^{1}$, Gilka Paiva Oliveira Costa ${ }^{1}$, Francisca Vilena da Silva ${ }^{1}$, Sandra Aparecida de Almeida ${ }^{1}$

\begin{abstract}
Objective: to understand the access of lesbians, gays, bisexuals and transvestites/transsexuals to the Basic Family Health Units. Methods: qualitative research held with 54 patients. A semi-structured interview and the free association test were used. The data were processed by the software IRaMuTeQ® and submitted to the technique of Content Analysis in the thematic modality. Results: six categories emerged: Silencing regarding sexual orientation and gender identity - access is facilitated as they do not reveal themselves; Invisibility and indifference to legal political references - antagonism between the paradigm thought and executed; Homophobic manifestations and effects on access - restricted use of the service; Embarrassment and distancing - removal and search for private services; Des (humanized) and unethical practices - lack of awareness, secrecy; and Stigma and access - permanence of stigmata between Acquired Immunodeficiency Syndrome and homosexuality. Conclusion: the access to health services is limited with intolerance, constraints, exclusionary and aerial positions.
\end{abstract}

Descriptors: Health Services Accessibility; Family Health; Sexual and Gender Minorities.

Objetivo: compreender o acesso de lésbicas, gays, bissexuais e travestis/transexuais às Unidades Básicas de Saúde da Família. Métodos: pesquisa qualitativa, realizada com 54 usuários(as). Utilizou-se entrevista semiestruturada e o teste de associação livre de palavras. Os dados foram processados pelo software IRaMuTeQ® e submetidos à técnica de Análise de Conteúdo na modalidade temática. Resultados: emergiram seis categorias: Silenciamento quanto à orientação sexual e identidade de gênero - o acesso é facilitado desde que não se revelem; Invisibilidade e indiferença aos marcos políticos legais- antagonismo entre o paradigma pensado e executado; Manifestações homofóbicas e efeitos no acesso - uso restrito do serviço; Constrangimento e distanciamento - afastamento e busca por serviços privados; Práticas des(humanizadas) e antiéticas - falta de sensibilização, sigilo; e Estigma e acesso - permanência de estigmas entre Síndrome de Imunodeficiência Adquirida e homossexualidade. Conclusão: o acesso desta população aos serviços de saúde é limitado, permeado por intolerância, constrangimentos e posicionamentos aéticos e excludentes.

Descritores: Acesso aos Serviços de Saúde; Saúde da Família; Minorias Sexuais e de Gênero.

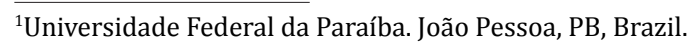

Corresponding author: Geane Silva Oliveira

Rua Ernesto de Sousa Diniz, 409, Jardim Oásis - CEP: 58900-000. Cajazeiras, PB, Brazil. E-mail: geane1.silva@hotmail.com 


\section{Introduction}

Since the implantation of the Brazilian Unified Health System, technical-administrative and organizational devices have been available to promote greater equity in access and integrality of health care. It was invested in the strengthening of Primary Health Care services and consolidation of the Family Health Strategy as a gateway to the health system. Therefore, these services play a central role in ensuring that the population has access to quality healthcare, and must produce comprehensive care that considers the individual in its singularity and sensitive to socio-cultural, ethnic, religious and sexual specificities/diversities ${ }^{(1)}$.

With the commitment to promote inclusion and reduce the inequalities of access of specific groups, such as the lesbian, gay, bisexual, transvestite and transsexual population, the Ministry of Health through Ordinance $\mathrm{N}^{\circ}$ 2,836, instituted the Policy National Center for Integral Health of Lesbian, Gay, Bisexual, Transvestite and Transsexual in 2011, reinforcing its importance and historical character for the needs of an invisible and violated population in their rights $^{(2)}$.

This policy recognizes the effects of discrimination and exclusion in the health-disease process of these social groups by establishing concrete proposals to be implemented in all spheres of management of the Unified Health System. It also aims to reduce institutional prejudice and ensure respect for differences, promote access to the different points of the health services network, guarantee quality and resolutive assistance, promote initiatives aimed at harm reduction, guarantee the use of the social name and legitimize the social participation of this population in Councils and Deliberative Bodies of instances of social and health status ${ }^{(2)}$.

Although important advances in the Brazilian context are noticed, it is observed that the access of this group to the health services is permeated by obstacles. Studies have identified difficulties in the communication process, selective listening, rejection, dis- criminatory reactions, verbal offenses and symbolic barriers $^{(3-4)}$.

However, cultural elements from the heterosexual pattern influence the care of health professionals to this population in a subjective way. Therefore, changes in the modus operandi of the healthcare network to promoting more qualified care also depend on changes in the way these professionals think and $\operatorname{act}^{(5)}$. It is well known that situations of discrimination and institutional prejudice as well as unpreparedness, lack of knowledge about gender identity and expression and sexual orientation, together with complete neglect and ignorance are at the core of the issue and much needs to be done to reverse minimally the effects of years of exclusion and invisibility ${ }^{(6)}$.

Therefore, this study is important because of the patients' view of their specificities and access to public health services in Brazil, especially in a city in the interior of the state of Paraíba. The strengthening of the health actions aimed at this group is also reinforced to promote strategies to minimize the impact of the identified gaps. Thus, it is questioned: how does the access of lesbian, gay, bisexual and transvestite/ transsexuals to the health services of the Family Health Strategy occur? To answer this question, the objective is to analyze from the perspective of lesbians, gays, bisexuals and transvestites/transsexuals, their access to the health services of the Basic Family Health Units.

\section{Methods}

This is a qualitative study carried out in an association of lesbian, gay, bisexual and transvestite/ transsexual people from Cajazeiras-PB, Brazil. The definition of the sample was based on the population base of the 32 associates and the others, identified by the snowball sampling method. Therefore, it was characterized in a non-probabilistic sample, using linear reference chains, where each participant indicated a possible participant until the repetition of indications and exhaustion of participation possibilities ${ }^{(7)}$. After 
the application of this procedure and its saturation, there was a quantitative of 54 interviewees. As inclusion criteria, it was considered self-declaration of lesbian, gay, bisexual and transvestite/transsexuals, and aged over 18 years old. People with a diagnosis of psychiatric and non-literate disorders were excluded.

Data collection took place from March to June 2016, by appointment. To obtain the data, it was used: 1) a structured form containing sociodemographic information (age, sex, gender, race/skin color, income, education level, sexual orientation); 2) a semi-structured interview that included questions related to the access to health services; ) Free Word Association Test using as an inducing stimulus the following phrase: when I say access to the services of the Basic Family Health Units for lesbian, gay, bisexual and transvestite/transsexuals, tell me five things that immediately come to your head. From the free evocations from the Free Association of Words Test, the lexicographic dictionary was elaborated, which was sent to two experts to determine the root word and its derived words. After devolution of the experts, the substitutions of words derived by the root words were made.

With the results of the 54 interviews transcribed in full and the lexicographic dictionary, the database for processing in the software IRaMuTeQ (Interface de R pour les Analyses Multidimensionnelles de Textes et de Questionnaires) was elaborated. Operationally, this software performs the Descending Hierarchical Classification, with the purpose of classifying the text segments according to their respective vocabularies, dividing it based on the frequency of the reduced forms, besides allowing a lexographic analysis of the text, pointing to the emergence of contexts (classes), categorized according to the segments of shared texts ${ }^{(8)}$.

After reading the archived material, the analytical model was composed of the word classes generated by the IRaMuTeQ software. The interpretative analysis of the corpus was given by the Content Analysis Technique in the thematic modality ${ }^{(9)}$.

The corpus contains the following variables: age group: id_1 age between 25-36 years old, id_2 age between 37-48 years old, id_3 age above 49 years old; sex: female sex_1, male sex_2. The classification of the age groups was made from the lowest and the highest age of the study individuals.

The categories generated represented the sense environment of words: access or exclusion of lesbians, gays, bisexuals and transvestites/transsexuals to the services of the Basic Family Health Units. The letter U was listed to relate the users' speeches to the speech segments described.

This study followed all the formal requirements in national and international regulatory standards for research involving human beings and it was approved by the Research Ethics Committee under nํㅜㄹ,382,819.

\section{Results}

The results show the sociodemographic characterization of the users participating in this research and their perceptions about the access to health services.

It was verified that $44(81.5 \%)$ of the participants declared themselves as male, $41(75.9 \%)$ of the male gender, three $(1.2 \%)$ belonging to the female gender and 38 (70.3\%) with homosexual orientation. Participants who declared female corresponded to $10(18.5 \%)$. There was predominance in the age group of 18 - 24 years old, represented by 35 (64.8\%). The race/skin brown color was self-reported by 32 (59.2\%), 23 (42.5\%) attended up to 12 years of study and $34(62.9 \%)$ reported monthly income between 1 and 3 minimum wages (62.9\%).

Through the user speech fragments, the partitions of the corpus emerged through IRaMuTeQ software, generating the following categories: Silencing regarding sexual orientation and gender identity; Invisibility and indifference to legal political references; Homophobic manifestations and effects on access; Embarrassment and distancing; Des (humanized) and unethical practices; and Stigma and access. 


\section{Category 1: Silencing sexual orientation and gender identity}

Category 1 has $13.0 \%$ of the corpus, composed of males and ages between 18 and 36 years old. It is observed that the speech fragments indicate the access to the Basic Family Health Unit free from obstacles, since they do not reveal real sexual orientation/ gender identity or any evidence that leads to this association: When I look for the health unit, I do not have any problem, because I am seen as society dictates as normal (U01). It is totally different with a transvestite, a masculinized lesbian... the difficulties are numerous and the main one is to expose the sexual orientation (U11). They never claimed gender in the unit, even seeing the hair or other traits... if I say my sexual orientation, then, yes, things would change, because of prejudice (U15).

\section{Category 2: Invisibility and indifference to legal political references}

Category 2 has $11.9 \%$ of the corpus and it is composed with greater representativeness of males and age between 18 and 25 years old. There is a lack of disclosure of the existence of the policy, since it is not exercised by the professionals of the family health team, as the fragments of statements below show: I have heard of a policy that helps in the orientation of sexual health, but this is not exercised... we wait for the rights (U05). There are public policies to propagate rights, but they are not disclosed (U15). Public policies are there, society and health professionals remain aware, putting them into practice and offering equal rights to improve access (U48).

\section{Category 3: Homophobic manifestations and effects on access}

Representing $17.3 \%$ of the corpus, this category composed of both sexes and age between 25 and 36 years old indicating that due to the homophobic manifestations the access is restricted, summarizing to the conduction of examinations and search of con- doms: People are not prepared to attend this people, I live the homophobia every day... we hope that, with politics, transvestites are treated well... the masculinized women... we have the right to equality in health (U29). The professionals do not call me by the social name... the access in the Basic Family Unit Health is not integral; I already went to get this service just to do exams and get condoms... (U45).

\section{Category 4: Embarrassment and distancing}

Category 4 is composed of $24.3 \%$ of the corpus, male and between 18 to 36 years old. These participants perceive the indifference and the embarrassment in the care, causing barriers and excluding them from the Basic Family Health Unit: It is embarrassing, as the way to act and to understand the person (U26). Disrespect, poor preparation of professionals ... I prefer to look for a private service, I feel more comfortable (U14). The embarrassment already happens at the reception; should have greater knowledge about sexuality to reduce or abolish problems (U15). There are different looks, jokes, giggles, that interfere with the care... nurses, when they see the way, the voice, the look, they already make fun (U21). The way people look, they embarrass us a lot... I hear insults, jokes, uncomfortable words just because I like the same gender as mine, I still hear that it's because I've never been with a man who made me a woman. They call me a little girl, little woman (U16) ... They see us as if we were clowns, comedians ... I hear jokes that make me sick (U18). When we arrive at the unit, there are the looks and, when I look, I am very bad assisted (U30).

\section{Category 5: Des (humanized) and unethical prac- tices}

It has $17.5 \%$ of the corpus, formed by males and aged between 25 and 48 years old. This category shows that the experience lived in healthcare spaces does not refer to a humanized and ethical assistance due to the lack of awareness and ethical secrecy of the workers of the Basic Health Unit: ...Most of the health workers are deprived of understanding or sensitivity (U19). Lack of preparation, sensitivity, information, humanization (U20). Professional secrecy in service is almost non-existent; lack of ethics, professional conduct, punishment for these professionals (U42, U46). 


\section{Category 6: Stigma and access}

Category 6 has $17.8 \%$ of the corpus, composed of male users and age between 25 and 36 years old. The content evidences the permanence of stigmatizing characteristics that associated Acquired Immunodeficiency Syndrome (AIDS) to homosexuality. The social discrimination that exists today may be associated with the particularities attributed to the disease, where people living with AIDS, in the past, for the most part, were homosexual: I went to the unit to perform a fast AIDS and syphilis test, I am different because the look that healthcare professionals have about us is this (U06). If I lost weight, I had AIDS, if I am gay, I have AIDS... once in blood donation, I identified myself as gay and the health professional said that I could not donate because I was gay, saying that the rates show that sexually transmitted diseases are much higher in this population (U13). Upon arriving at a health facility, I told the sexual option, so the professionals were soon doing the fast test (U48).

\section{Discussion}

Although Brazilian society is historically stratified and permeated by deep social inequalities, the asymmetries of social markers of difference, such as gender, sexual orientation, ethnicity/race, social class, converge and articulate producing economic, cultural and political vulnerabilities for certain social groups ${ }^{(10)}$. In the case of the lesbian, gay, bisexual, transvestite and transsexual population, the confluence of these markers accentuates discrimination, reinforces exclusion and hinders access to education, work, and healthcare.

In this study, the sociodemographic profile of the population investigated portrayed the predominance of young, brown, economically vulnerable and low education level individuals. Such characteristics determine and contribute to inadequate access to education, housing, work, health, public services and financial opportunities. A survey conducted in a deprived area in the city of Rio de Janeiro, involving 45 lesbian, gay, bisexual, transvestite and transsexual people, found that $50.0 \%$ dropped out, $57.0 \%$ depended on financial assistance from relatives, partners or friends and only $39.0 \%$ were employed, most of them with low remuneration ${ }^{(10)}$.

It is necessary to consider that, in addition to the professional disqualification and the limited opportunities to access the labor market, the discrimination and violence that this segment of the population suffers has a direct impact on health care needs: high blood pressure and anxiety about fear of diseases and violence, alcoholism, sexually transmitted infections, hormonal side effects, surgical complications, depression, and suicide attempt ${ }^{(11)}$.

However, although in the Unified Health System concrete measures are implemented to address the iniquities and inequalities in health of this population, their implementation requires improvement and awareness of health professionals to recognize and accommodate the demands and needs of this group ${ }^{(2)}$.

From the reports, it was observed that access to health services is assured to users who silence their sexual orientation or gender identity. However, when revealed, access to the Basic Health Unit can vary from restrictive to exclusive, generating embarrassment, psychological distress, social exclusion and physical aggravation.

A study conducted in the United States recruited 1,014 lesbian, gay, bisexual and transgender people living in rural areas to investigate the impact of exclusion and stigma when using the health services. Of the total sample, $37.0 \%$ did not use the services. Among those who attended, $43.0 \%$ reported that their sexual orientation or gender identity did not affect their health and $27.0 \%$ said that this information was not of interest to health professionals. Higher scores on the stigma scales were associated with lower use of health services for the transgender group. In general, $50.0 \%$ of the sample presented symptoms that may indicate a depressive picture, and among the transgender, this rate reached $65.0 \%$. Approximately one-third of respondents were diagnosed with one or more chronic diseases and $14.0 \%$ met the criteria for 
alcohol abuse. As a potential for increasing the use of health services, it was highlighted the need to expand the competencies of health professionals to provide individualized care ${ }^{(12)}$.

It is interesting to note that programs and/or projects that, in practice, translate policy guidance and policy decisions, do not guarantee implementation. Above all, they depend on how they are perceived and treated in the daily life of services. Participants in this study request that they have the same visibility as other users regardless of their sexual orientation or gender identity. The omission and lack of knowledge about the intrinsic and particular reality of the user can provide care (dis) care and pass on the person in a way to pathologize and/or medicalize their sexuality and/or gender identity ${ }^{(11)}$.

On the other hand, participants mentioned that the disclosure of sexual orientation or gender identity caused embarrassment during the care of the professionals because they did not know or deny the possibility of sexual and gender diversities, especially for transvestites, transsexuals and lesbians masculinized

The change of something that is dissociated from sociocultural, religious and educational standards results in actions that can determine postures, practices, and discourses and negatively interfere in the work process of health professionals, disregarding ethical precepts ${ }^{(6,13)}$. Therefore, the health teams need training and awareness in attending to this population not to generate barriers in the use of services ${ }^{(14-15)}$.

The humanization process implies a conversion in the process of thinking and acting of the user and the health professional to maintain respect and recognize the different possibilities of the experience of sexuality ${ }^{(13)}$. The subjective change of behavior connotes in team awareness, in which humanization is used with the purpose of assisting the user integrally, valuing, even more, the level of quality of care that is offered and provided. However, even if technical capacity prevails, the rights of this population must be respected in their singularities ${ }^{(16)}$.

However, this right is violated when the user detects that the professional adopts a posture contrary to ethical conduct, in the dissemination of information obtained during health practice. Professional secrecy is linked to ethical issues that pervade the technique. These awaken the dilemmas of professional practice by encouraging a reflexive attitude of reality, so they can overcome bureaucratic/technical acts, through non-prejudiced ethical actions ${ }^{(17)}$.

\section{Conclusion}

From the perspective of lesbians, gays, bisexuals and transvestites/transsexuals, the access to health services is still punctual, permeated by constraints and lack of ethical positions. Feelings of helplessness, exclusion, omission, and rejection remain in care despite the existence of specific Public Policies and training for professionals and users of health services.

\section{Collaborations}

Oliveira GS contributed to the design and project, analysis and interpretation of data, article writing. Nogueira JA and Costa GPO contributed to the analysis of the data and article writing. Silva FV contributed with the analysis and interpretation of the data and writing of the article. Almeida SA contributed to the analysis and interpretation of the data, essay writing, critical review of the intellectual content and final approval of the version to be published.

\section{References}

1. Ministério da Saúde (BR). Secretaria de Atenção à Saúde. Departamento de Atenção Básica. Portaria no 2.436, de 21 de setembro de 2017. Política Nacional de Atenção Básica. Brasília: Ministério da Saúde; 2017.

2. Ministério da Saúde (BR). Secretaria de Gestão Estratégica e Participativa. Política Nacional de Saúde Integral de Lésbicas, Gays, Bissexuais, Travestis e Transexuais. Brasília: Ministério da Saúde; 2013. 
3. Aragusuku HA, Lopes M. Preconceito, Discriminação e Cidadania LGBT: Políticas Públicas em Mato Grosso e no Brasil. Aceno [Internet]. 2016 [citado 2018 mar. 13]; 3(5):242-58. Disponível em:http://periodicoscientificos.ufmt.br/ojs/ index.php/aceno/article/download/3853/pdf

4. Silva JWSB, Silva Filho CN, Bezerra HMC, Duarte KVN, Quinino LRM. Políticas públicas de saúde voltadas à população LGBT e à atuação do controle social. Rev Saúde Pública Paraná. 2017; 18(1):1409.doi:http://dx.doi.org/10.22421/15177130.2017v18n1p140

5. Lima MDA, Souza AS, DANTAS MF. Os desafios a garantia de direitos da população LGBT no Sistema Único de Saúde (Sus). Rev Interfaces. 2016; 3(11):119-25. doi: 10.16891/2317-434X.377.

6. Duarte MJO. Diversidade sexual, políticas públicas e direitos humanos: Saúde e cidadania LGBT em cena. Temporalis [Internet]. 2014 [citado 2018 mar. 8]; 14(27):77-98. Disponível em: http:// periodicos.ufes.br/temporalis/article/view/7209

7. Vinuto J. A amostragem em bola de neve na pesquisa qualitativa: um debate em aberto. Temáticas [Internet]. 2014 [citado 2018 mar. 8]; 22(44):203-20. Disponível em: https://www.ifch. unicamp.br/ojs/index.php/tematicas/article/ view/2144/1637

8. Camargo BV, Justo AM. Iramuteq: um software gratuito para análise de dados textuais. Temas Psicol. 2013; 21(2):513-18. doi: http://dx.doi. org/10.9788/TP2013.2-16

9. Bardin L. Análise de conteúdo. São Paulo: Edições 70; 2016.

10. Kalume CC, Itaborahy LP, Moreira JCC. Vulnerabilidades socioeconômicas de pessoas LGBT no Rio de Janeiro [Internet]. 2016 [citado 2018 jun. 19]. Disponível em: https://microrainbow. org/wp-content/uploads/2017/05/Vulnerabilidades-socioecon\%C3\%B4micas-de-pessoas-LGBT-no-Rio-de-Janeiro-artigo-completo. pdf
11. Bittencourt D, Fonseca V, Segundo M. Acesso da população LGBT moradora de favelas aos serviços públicos de saúde: entraves, silêncios e perspectivas. Conexões PSI [Internet]. 2014 [citado 2018 mar. 8]; 2(2):60-85. Disponível em:https://promundo.org.br/recursos/acessoda-populacao-lgbt-moradora-de-favelasaosservicos-publicos-de-saude-entravessilencios-e-perspectivas/

12. Whitehead J, Shaver J, Stephenson R. Outness, stigma, and primary health care utilization among rural LGBT populations. PLoS ONE. 2016; 11(1):e0146139. doi: https://doi.org/10.1371/ journal.pone.0146139

13. Vianna CP. O movimento LGBT e as políticas de educação de gênero e diversidade sexual: perdas, ganhos e desafios. Educ Pesq. 2015; 41(3):791806. doi: http://dx.doi.org/10.1590/s151797022015031914

14. Munson S, Cook C. Lesbian and bisexual women's sexual healthcare experiences. J Clin Nurs. 2016; 25(23-24):3497-510. doi: https://doi. org/10.1111/jocn.13364

15. Chapman R, Wardrop J, Freeman P, Zappia T, Watkins R, Shields L. A descriptive study of the experiences oflesbian, gay and transgender parents accessing health services for their children. J Clin Nurs. 2012; 21(7-8):1128-35. doi: https://doi. org/10.1111/j.1365-2702.2011.03939.x

16. Mazzi RAP, Oliveira LYQ Dorsa AC. O discurso da humanização da assistência hospitalar no Brasil sob a ótica analítica de Van Dijk. Rev Cont Cienc Soc [Internet]. 2017 [citado 2018 mar. 9]. Disponível em: http://www.eumed.net/rev/cccss/2017/03/ discurso-assistencia-hospitalar.html

17. Sampaio SS, Rodrigues FW. Ética e sigilo profissional.ServSoc Soc. 2014; (117):84-93. doi: http://dx.doi.org/10.1590/S0101-66282014000100006 